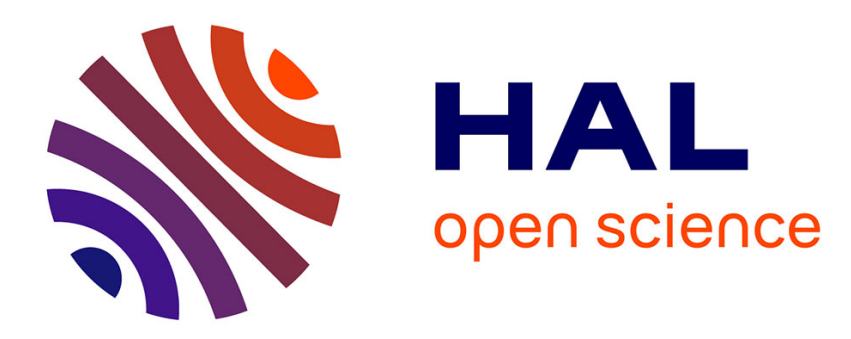

\title{
Which European regulation for security tokens?
}

Bruno Mathis

\section{To cite this version:}

Bruno Mathis. Which European regulation for security tokens?. 2020. hal-02477376

\section{HAL Id: hal-02477376 \\ https://essec.hal.science/hal-02477376}

Preprint submitted on 13 Feb 2020

HAL is a multi-disciplinary open access archive for the deposit and dissemination of scientific research documents, whether they are published or not. The documents may come from teaching and research institutions in France or abroad, or from public or private research centers.
L'archive ouverte pluridisciplinaire $\mathbf{H A L}$, est destinée au dépôt et à la diffusion de documents scientifiques de niveau recherche, publiés ou non, émanant des établissements d'enseignement et de recherche français ou étrangers, des laboratoires publics ou privés. 


\section{Which European regulation for security tokens?}

Author

Bruno Mathis

Independent researcher

Associate expert to the Centre européen de droit et d'économie

bmathis@cegetel.net 


\section{TABLE OF CONTENTS}

INTRODUCTION

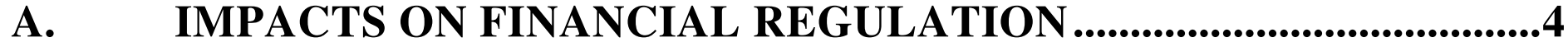

1. IMPACTS ON THE MARKETS IN FINANCIAL INSTRUMENTS DiRECTIVE.............................4

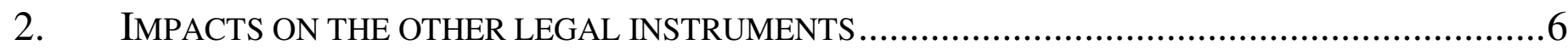

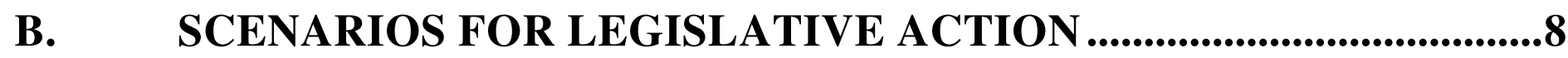

1. A MINIMUM ADAPTATION OF FINANCIAL REGULATION..................................................

2. A COMPREHENSIVE UPDATE OF FINANCIAL REGULATION ...........................................

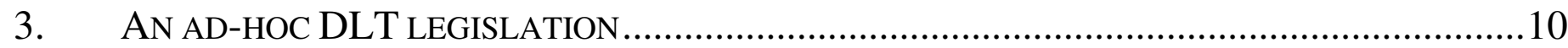

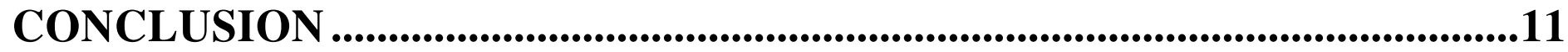

\section{Introduction}

While bitcoin ${ }^{1}$ was born in 2008, the study of possible applications of the blockchain, its underlying protocol, began in 2014. The blockchain is indeed the most emblematic distributed ledger technology (DLT), where the distributed ledger is defined as a type of database shared across nodes in a network ${ }^{2}$. DLT allows the circulation of digital tokens, generally classified into three categories: utility tokens, which are used to consume digital services, payment tokens, such as Bitcoin, which are used as a medium of exchange, and investment tokens, or security tokens ${ }^{3}$, which are financial assets. DLT obviously raises many legal issues, which

\footnotetext{
${ }^{1}$ S. Nakamoto, Bitcoin : A peer to Peer Electronic Cash System, 31 october 2008.

${ }^{2}$ For a detailed presentation, see D. Yaga, P. Mell, N.Roby \& K. Scarfone, "Blockchain Technology Overview", NISTIR 8202, NIST, October 2018.

${ }^{3}$ The terms "security token", "investment token" or "tokenized security" are used interchangeably.
} 
are already well covered by the academic literature ${ }^{4}$.

The financial sector began to take an interest in DLT at a time when the drafting of the main financial regulations developed in response to the subprime crisis in Europe was barely completed. Since then, research has focused particularly on the impacts on securities law ${ }^{5}$, while the wave of Initial Coin Offerings (ICO) ${ }^{6}$, between 2015 and 2018, led regulators to question the extent to which these new instruments fall within their remit. In its advice delivered in January 2019, the European Securities and Markets Authority (ESMA) lists the regulatory implications of a crypto-asset that would qualify as a financial instrument ${ }^{8}$ and suggests that legislative action would be welcome ${ }^{9}$. Some jurisdictions, in Europe and elsewhere, have taken the initiative ${ }^{10}$, but few specifically target investment tokens. The European Commission just launched in January 2020 a public consultation on crypto-assets in the form of a heavy questionnaire, whose last part addresses security tokens ${ }^{11}$.

ICOs raised in 2017 just over 6 billion dollars of capital worldwide ${ }^{12}$ when public offers of shares raised 927 billion $^{13}$ and those of bonds 6085 other billion the same year ${ }^{14}$. DLT could significantly reduce back-office costs of financial instruments as well as their risks ${ }^{15}$. Investors

\footnotetext{
${ }^{4}$ See for instance D. Kraus, T. Obrist and O. Hari (dir.), Blockchains, Smart Contracts, Decentralised Autonomous Organisations and the Law, Edward Elgar Publishing, London, 26 April 2019 ; Y. Poullet \& H. Jacquemin, « Blockchain: une révolution pour le droit? », Journal des tribunaux, Larcier, November 2018 ; D. Zetsche, R. Buckley \& D. Arner, "The Distributed Liability of Distributed Ledgers: Legal Risks of Blockchain", EBI Working Paper Series, n 4, 2017.

${ }^{5}$ See for instance J. Benjamin, F. Snagg, M. Yates, "The medium is the message : how can the development of DLT improve upon the workings of the indirect holding system for intermediated securities?", Journal of International Banking and Financial Law, 1er November 2019 ; T. Cremers, «La blockchain et les titres financiers : retour vers le futur », Bulletin Joly Bourse - ${ }^{\circ} 06,1^{\text {st }}$ June 2016, page 271 ; Mélanges en l'honneur de Jean-Jacques Daigre - Autour du droit bancaire et financier et au-delà, Editions Joly, 2017, p. 539 ; P. Hacker \& C. Thomale, « Crypto-Securities Regulation: ICOs, Token Sales and Cryptocurrencies under EU Financial Law », European Company and Financial Law Review, 645-696 (2018) ; P. Paech, « Securities, Intermediation and the Blockchain: An Inevitable Choice between Liquidity and Legal Certainty? » LSE Law, Society and Economy Working Paper 20/2015, Uniform Law Review (2016) 21 (4).

${ }^{6}$ For more details, see I. Barsan, « Legal Challenges of Initial Coin Offerings (ICO) », RTDF, n 3, 2017, pp. 54-65 ; M. Chanson, M. Risius \& F. Wortmann, Initial Coin Offerings (ICOs): An Introduction to the Novel Funding Mechanism Based on Blockchain Technology, Conference paper, ResearchGate, January 2018.

${ }^{7}$ ESMA, «Initial Coin Offerings and Crypto-Assets », Advice, 9 January 2019.

${ }^{8}$ Ibid., section VII.

${ }^{9}$ Ibid., $\$ 16$.

${ }^{10}$ See M. Rauchs et al., Global cryptoasset regulatory landscape, Cambridge Center for Alternative Finance, April 2019.

${ }^{11}$ European Commission, Financial services - EU regulatory framework for crypto-assets, 19 December 2019.

${ }^{12}$ C. Le Moign, ICO françaises : un nouveau mode de financement?, Autorité des marchés financiers, November 2018 , p. 8.

${ }^{13}$ World Federation of Exchanges, H1 2018 Market Highlights Report, 7 August 2018, p. 5.

${ }^{14}$ World Federation of Exchanges, WFE Annual Statistics Guide (Volume 4), $1{ }^{\text {st }}$ May 2019, sheet "Bond".

${ }^{15}$ M. Mainelli \& A. Milne, The Impact and Potential of Blockchain on the Securities Transaction Lifecycle, The SWIFT Institute, 9 May 2016 ; Oliver Wyman and Euroclear, Blockchain in Capital Markets - The Prize and the Journey, February 2016.
} 
should face the prospect of directly holding securities issued anywhere in the world ${ }^{16}$. The opportunity for the shareholder to exercise his voting rights from his tokens and the intrinsic traceability of the transactions in the DLT should foster good corporate governance ${ }^{17}$. In Europe, while an implementing regulation has recently been adopted to facilitate the identification of shareholders and the exercise of their rights ${ }^{18}$, these features could be put to good use ${ }^{19}$.

These opportunities justify the consideration of a legislative approach specifically targeting security tokens. The purpose of this article is therefore to identify the areas of European financial law that would need to be adapted so that financial securities could circulate in the form of tokens $(A)$, then to describe three possible scenarios for legislative action by the European Commission (B).

\section{A. Impacts on financial regulation}

The inclusion of security tokens in financial regulation requires, first of all, a revision of the Markets in Financial Instruments Directive (MiFID) ${ }^{20}$, which is its linchpin (1). We will then examine the other texts concerned (2).

\section{Impacts on the Markets in Financial Instruments Directive}

MiFID brings with it the application of other texts which, for the definition of transferable securities, refer, directly or indirectly, to the definition contained in Article 4(1)(44) :

«'transferable securities' means those classes of securities which are negotiable on the capital market, with the exception of instruments of payment, such as :

\footnotetext{
${ }^{16}$ E. Micheler, "Custody chains and asset values: why crypto-securities are worth contemplating", Cambridge Law Journal, 2015.

${ }^{17}$ G. Geis, "Traceable Shares and Corporate Law", Northwestern University Law Review, v. 113, forthcoming (2019) ; S. Blemus \& D. Guégan, "Initial Crypto-asset Offerings (ICOs), tokenization and corporate governance", Columbia Law School blog on corporations and capital markets, $1^{\text {st }}$ May 2019.

18 Commission Implementing Regulation (EU) $n^{\circ} 2018 / 1212$ (...) of 3 September 2018 laying down minimum requirements implementing the provisions of Directive 2007/36/EC (...) as regards shareholder identification, the transmission of information and the facilitation of the exercise of shareholders rights.

19 C. van der Elst \& A. Lafarre, "Blockchain and Smart Contracting for the Shareholder Community", European Business Organisation Law Review, Springer, 19 January 2019.

${ }^{20}$ Directive 2014/65/EU (...) of 15 May 2014 on markets in financial instruments.
} 
(a) shares in companies and other securities equivalent to shares in companies, partnerships or other entities, and depositary receipts in respect of shares;

(b) bonds or other forms of securitised debt, including depositary receipts in respect of such securities;

(c) any other securities giving the right to acquire or sell any such transferable securities or giving rise to a cash settlement determined by reference to transferable securities, currencies, interest rates or yields, commodities or other indices or measures $»$.

The investment token may be included in this definition, where "such as" means that the descriptions in (a), (b) and (c) do not constitute an exhaustive list ${ }^{21}$. This flexibility has been useful to investment banks that have been able to issue derivatives, in the form of depositary receipts or warrants, as securities. On the same principle, investment tokens can be created as depositary receipts representing securities issued off-chain. The international securities services association calls them "asset-backed securities tokens" ${ }^{22}$.

The formulations in (a) and (b) of paragraph 44 are also workable, since they include depositary receipts. The following paragraph 45 defines these as "securities which are negotiable on the capital market and which represent ownership of the securities of a nondomiciled issuer while being able to be admitted to trading on a regulated market and traded independently of the securities of the non-domiciled issuer". This definition could be extended to a second case: a security, shaped as a token, negotiable on the capital market, which represents securities issued by book-entry and may trade independently of such book-entry securities. This solution avoids any friction with each Member State's corporate law or contract law, but reduces the economic potential of DLT. Financial institutions might issue depositary receipts only for the most liquid securities.

Finally, another solution would be to supplement paragraph 44 with a sentence such as: "a security may take the form of a book-entry or a token/registration based on distributed registry technology".

As regards trading platforms, a first variant could be to amend the provisions governing the three existing types of platforms, the regulated market, the multilateral trading facility (MTF) and the organized trading facility (OTF). However, these amendments could be cumbersome for the former and ill-suited to the latter, which is aimed at securities with proven liquidity. The DLT-based exchange (DLE) could be considered as a new form of OTF, but it does not

\footnotetext{
${ }^{21}$ T. Maas, Initial Coin Offerings: "When Are Tokens Securities in the EU and US?", SSRN, 9 April 2019, p. 48 et s.

${ }^{22}$ ISSA, Crypto Assets: Moving from Theory to Practice - White paper, November 2019, p. 5.
} 
include equities and is designed for professionals. We will only consider here the hypothesis of a DLE as a fourth type of platform, exclusive of the existing three ones.

The directive could stipulate that tokenized securities offered to the public would be traded on a DLE. The operator of the DLE could offer an ancillary clearing service and a service for trading in tokens that are not representative of securities, as is the case in the Swiss draft legislation ${ }^{23}$. It would perform a notary function: responsible for the integrity of the issue, it would deploy the smart contract and its software updates, and would inject the data relating to securities transactions.

\section{Impacts on the other legal instruments}

Other regulations and directives are concerned:

- The MIFIR Regulation ${ }^{24}$ is most deeply affected. Transparency rules for trading platforms ${ }^{25}$ and systematic internalizers ${ }^{26}$ probably deserve to be revisited, taking into account the naturally decentralised nature of the transactions and the different levels of access rights granted to participants. The same goes to the reporting rules ${ }^{27}$, taking advantage of the opportunity for the regulator itself to become a participant in the register $^{28}$. ESMA could be invite to propose technical standards that would apply to tokenised securities and DLEs.

- In the Central Securities Depositories Regulation (CSDR) ${ }^{29}$, Article 3(2) provides that "when a securities transaction takes place on a trading venue, the relevant securities shall be registered in a book-entry account with a [central securities depository] on or before the agreed settlement date, if they were not already registered". The provision could be made subject to the additional condition that they have not been tokenized. The Member State that so wishes could maintain this requirement for security tokens. On the

\footnotetext{
23 Swiss Federal Council, Loi fédérale sur l'adaptation du droit fédéral aux développements de la technologie des registres électroniques distribué -, Rapport explicatif relatif au projet mis en consultation, Bern, 22 March 2019 , p. 48 et s.

${ }^{24}$ Regulation (EU) N ${ }^{0} 600 / 2014$ (...) of 15 May 2014 on markets in financial instruments.

${ }^{25}$ Title II of the Regulation.

26 Title III.

${ }^{27}$ Title IV.

${ }^{28}$ R. Auer, "Embedded supervision: how to build regulation into blockchain finance", BIS Working Papers, n811, September 2019.

${ }^{29}$ Regulation (EU) $\mathrm{N}^{\mathrm{o}} 909 / 2014$ (...) of 23 July 2014 on improving securities settlement in the European Union and on central securities depositories.
} 
other hand, the settlement discipline ${ }^{30}$ that is due to enter into force in September 2020 is not applicable to distributed ledgers. A specific one will have to be devised for security tokens.

- The new "Prospectus 3 » Regulation ${ }^{31}$ would apply to securities represented either by book-entries or by tokens. It could be amended to require the issuer to describe in the prospectus the nature of the tokens and the functions of the smart contract reserved for the issuer or its subcontractor and those made available to investors ${ }^{32}$. It could compel the issuer to publish in a supplemental prospectus ${ }^{33}$ any serious operational incident related to the operation of its securities under a distributed ledger.

- For its part, the Settlement Finality Directive (SFD) ${ }^{34}$ is challenged by the issue of the irrevocability of transactions recorded with DLT. The point at which a settlement can be considered final is difficult to determine in a distributed ledger. The ECB refers to the problem as 'probabilistic finality', depending on the method of transaction validation used, in which transactions already processed could be retroactively revoked by replacement transactions ${ }^{35}$.

- The Fourth Modified Anti-Money Laundering Directive ${ }^{36}$ will also sooner or later have to be reviewed in the light of the guidelines, produced by the Financial Action Task Force (FATF), on what it now calls "virtual assets" ${ }^{37}$. In particular, the FATF advocates that national law enforcement authorities must be able to freeze virtual assets that have been ordered by a court decision ${ }^{38}$. On the other hand, according to its Recommendation 16 on wire transfers, the details of the originator and beneficiary must be communicated immediately with the asset transfer order, by any secure means. This rule, known as the "Travel Rule", applies primarily to payment tokens, but also to the free transfer of

${ }^{30}$ Commission Delegated Regulation (EU) 2018/1229 of 25 May 2018 supplementing Regulation (EU) No 909/2014 (...) with regard to regulatory technical standards on settlement discipline.

${ }^{31}$ Regulation (EU) 2017/1129 (...) of 14 June 2017 on the prospectus to be published when securities are offered to the public or admitted to trading on a regulated market.

${ }^{32}$ Ibid., Art. 13.

${ }^{33}$ Ibid., Art. 23.

${ }^{34}$ Directive 98/26/EC (...) of 19 May 1998 on settlement finality in payment and securities settlement systems.

${ }^{35}$ ECB, The potential impact of DLTs on securities post-trading harmonisation and on the wider EU financial market integration, September 2017, p. 53-58.

${ }^{36}$ Directive (EU) 2018/843 (...) of 30 May 2018 (...) on the prevention of the use of the financial system for the purposes of money laundering or terrorist financing.

${ }^{37}$ FATF-GAFI, Guidance for a risk-based approach to virtual assets and virtual assets services providers, 21 June 2019.

${ }^{38}$ Ibid., §68. 
investment tokens ${ }^{39}$.

- The Regulation on financial institutions' capital requirements $(C R R)^{40}$ could have its scope extended to DLEs. For the sake of operational risk ${ }^{41}$, it could also provide for a specific capital allocation to crypto-assets, including investment tokens and their derivatives. Tokens are exposed to a risk of theft or loss that is out of all proportion to what is experienced on the book-entry securities markets ${ }^{42}$. These are not the only operational risks specific to the DLE, but they alone could justify such a review.

- The Financial Collateral Directive (FCD) ${ }^{43}$ would need to be developed, not only to extend it to the concept of the wallet, but also to take advantage of the escrow function driven by smart contract.

- Finally, the Regulation on shareholder identification ${ }^{44}$ could provide for terms and conditions for the exercise of shareholders' voting rights at shareholders' meetings applicable to security tokens.

The reader will find in annex a more complete summary of the impacts of tokenisation on the European texts concerning financial instruments.

\section{B. Scenarios for legislative action}

We consider here three scenarios: a minimal adaptation of financial regulation to DLT (1), a more comprehensive update, enriched by a harmonisation of national securities ownership regimes (2), and finally the setup of a DLT ad-hoc regime, outside the financial regulation, that would encompass utility and payment tokens (3).

\footnotetext{
${ }^{39}$ Ibid., $§ 111$ et $\mathrm{s}$.

${ }^{40}$ Regulation (EU) $n^{\circ} 575 / 2013$ (...) of 26 June 2013 on prudential requirements for credit institutions and investment firms.

${ }^{41}$ Within the meaning of Article 4(1)(52):' the risk of loss resulting from inadequate or failed internal processes, people and systems or from external events, and includes legal risk'.

${ }^{42}$ See EY Research, « initial coin offerings (ICOs) », December 2017, p. 2.

${ }^{43}$ Directive 2002/47/EC (...) of 6 June 2002 on financial collateral arrangements.

${ }^{44}$ Commission Implementing Regulation (EU) 2018/1212 of 3 September 2018 laying down minimum requirements implementing the provisions of Directive 2007/36/EC (...) as regards shareholder identification, the transmission of information and the facilitation of the exercise of shareholders rights.
} 


\section{A minimum adaptation of financial regulation}

This scenario would consist in limiting the scope of the changes to be made to the financial regulations, even if it means including a review clause a few years later.

A minimum adaptation of the regulations will necessarily include a review of MiFID and its associated Regulation. The CSDR will also have to be amended, as well as the delegated Regulation "Prospectus 3".

On the other hand, revisions of the SFD and FCD directives can be postponed and considered in a broader legislative package on the harmonisation of securities law. Security tokens would be temporarily ineligible as collateral for open positions with a central counterparty. Updates of regulations on market infrastructure and securities financing can wait for the security token markets to become more liquid. Another update of the CRR regulation may be subordinated to a significant increase in the outstanding amount of investment tokens among the assets held by investment firms. Finally, assuming that short selling is operationally possible with DLT, there is also no urgent need to revise the SSR Regulation ${ }^{45}$, whose adoption was motivated, as in the case of the CSDR, by the prevention of systemic risk ${ }^{46}$.

\section{A comprehensive update of financial regulation}

The diversity of national systems of securities ownership within the European Union was identified as early as 2003 by the first Giovannini Report as one of the 15 "barriers" to the development of cross-border securities transactions ${ }^{47}$. The Securities Law Directive (SLD) drafted in 2010 has not been finalized, and the European Commission concluded in 2018 that the existing conflict-of-law provisions specific to collateral, settlement finality and liquidation were sufficient as needed ${ }^{48}$.

This scenario would consist of adapting the existing financial regulation, as in scenario 1, by supplementing it with a new SLD. The tokenisation of securities is indeed an opportunity to re-open the discussion in a new light, including the consideration of a new form of real right

\footnotetext{
${ }^{45}$ Regulation (EU) $n{ }^{\circ}$ 236/2012 of 14 March 2012 on short selling and certain aspects of credit default swaps.

${ }^{46}$ Ibid., Recital.

${ }^{47}$ European Commission, European Post Trade Forum Report, 15 May 2017, p. 95.

${ }^{48}$ European Commission, Communication (...) on the applicable law to the proprietary effects of transactions in securities, $\operatorname{COM}(2018) 89$ final, 12 March 2018.
} 
for digital assets ${ }^{49}$.

In some Member States, such as Germany or Finland, it is the securities account maintained by the CSD that locates the property rights. If the CSD were to be disintermediated from the security token processing chain, these countries would then be obliged to define in their national law an ad-hoc ownership regime for security tokens. In the absence of harmonisation of ownership regimes across the whole range of securities, this should be easier at least on the reduced scope of tokenized securities, in the absence of pre-existing legislation in the Member States. Hacker \& Thomale also suggest the principle of an international convention on "crypto-securities"50. Nor should the principle of full harmonisation of securities law at European or international level be disregarded.

\section{An ad-hoc DLT legislation}

A last scenario, the setup of an ad-hoc regime, on DLT or crypto-assets, could be favoured by the European Commission. It could be part of the strategy for a digital single market ${ }^{51}$. Some researchers prefer it because of the blurred boundaries between the different categories of tokens ${ }^{52}$. Hybrid tokens could be allowed without specific restrictions.

It would allow to simultaneously address the issue of payment tokens, which are more visible to the general public. It would also be preferred by countries with less developed financial markets or those that already have a transparent intermediation system. In order to avoid any collision with financial regulation, no token would be deemed to be a financial instrument within the meaning of MiFID.

The advantage of this scenario is that it allows the three types of tokens to have common Know Your Customer (KYC) and private key protection requirements as part of the fight against money laundering. Provisions on market abuse or consumer protection would also be relevant for all categories of tokens. More restrictive rules on the segregation of tokens than those reserved under EU law for book-entry securities could be adopted.

It would also address issues specific to the law of evidence, and ensure consistency with

\footnotetext{
${ }^{49}$ H. de Vauplane, « Blockchain and intermediated securities », Kramer Levin, 2018.

${ }^{50}$ P. Hacker \& C. Thomale, op. cit., p. 43.

${ }^{51}$ European Commission, « Digital Single Market - Policy - Blockchain technologies ».

${ }^{5}$ See D. Boreiko, G. Ferrarini, P. Giudici, "Blockchain Startups and Prospectus Regulation", European Business Organization Law Review, Vol. 10, December 2019.
} 
other non-sector-specific regulations, such as the GDPR ${ }^{53}$, the elDAS Regulation ${ }^{54}$, and the NIS Directive ${ }^{55}$.

The supervision of compliance obligations relating to all these subjects could then be mandated to a single authority dedicated to DLT. This is the approach adopted by Malta in setting up the Malta Digital Innovation Authority, except that its remit extends beyond DLT to all technological innovation.

However, the drawback of this scenario is that it breaks with the principle of technological neutrality hitherto sought by scholars and legislators alike. It creates a risk of regulatory arbitrage, with investment tokens having the economic characteristics of financial instruments without bearing the compliance burden. It also exposes itself to the risk of adherence to the proposed regulation on crowdfunding, which is currently being examined. This regulation is likely to serve as a framework for ICOs and therefore at least for utility tokens ${ }^{56}$.

A choice will have to be made between two strategies for the legal alignment of investment tokens. Their regime can be harmonised at European level with that of utility and payment tokens, or harmonised with that of securities issued by book entry, but not both at the same time.

\section{Conclusion}

To allow the use of tokens for tradeable securities, those for which the savings potential in post-trading is greatest, it would be necessary to begin by breaking the lock of Article 3 (2) of CSDR. To organize this new market, it might be necessary to have an intermediary status dedicated to DLT, similar to that envisaged by Switzerland, and thus to accept the limits of the quest for technological neutrality. These two key measures could be an interim measure proportionate to a context without a systemic risk for the moment, and would be enough for professionals to take action.

\footnotetext{
${ }^{53}$ Regulation (EU) 2016/679 (...) of 27 April 2016 on the protection of natural persons with regard to the processing of personal data and on the free movement of such data.

${ }^{54}$ Regulation (EU) No 910/2014 (...) of 23 July 2014 on electronic identification and trust services for electronic transactions in the internal market.

${ }^{55}$ Directive (EU) 2016/1148 (...) of 6 July 2016 concerning measures for a high common level of security of network and information systems across the Union.

${ }_{56}$ M. Dell'Erba, "Stablecoins in Cryptoeconomics. From Initial Coin Offerings (ICOs) to Central Bank Digital Currencies (CBDCs)" (juin 2019), New York University Journal of Legislation and Public Policy, forthcoming, p. 35.
} 
Even if the European Union continues to prefer the resolution of conflicts of law on a case-bycase basis rather than a harmonization of national securities laws, a substantive debate on the nature of rights on and of securities as well as on and of the different categories of tokens may be necessary.

There is no doubt that legislative action will be taken in this area elsewhere in the world. Countries with no capital markets or sectoral interests to preserve have much to gain from opening up their financial law to DLT. European issuers might be tempted to make their public offer of securities in their Member State and then direct their investors to a crypto-asset trading platform outside the EU - whether regulated or not - to escape the constraint of Article 3 (2) of the CSDR.

The fear that the listing of European companies slips from its jurisdiction is perhaps what will lead the Commission to take an initiative. 


\section{ANNEX : European texts impacted by security tokenization}

\begin{tabular}{|c|c|c|c|}
\hline ELI identifier & short name & $\begin{array}{r}\text { legal } \\
\text { basis }\end{array}$ & $\begin{array}{l}\text { adhe- } \\
\text { rences }\end{array}$ \\
\hline https://eur-lex.europa.eu/eli/dir/1997/9/oj & Compensation & & $\begin{array}{l}4 \\
8\end{array}$ \\
\hline https://eur-lex.europa.eu/eli/dir/1998/26/oj & SFD & & $2(I)$ \\
\hline https://eur-lex.europa.eu/eli/dir/2001/24/oj & Winding-up & & 24 \\
\hline https://eur-lex.europa.eu/eli/dir/2002/47/oi & FCD & & 9 \\
\hline http://eur-lex.europa.eu/eli/dir/2004/109/oj & TD & & MIF 4 (1) (21) \\
\hline https://eur-lex.europa.eu/eli/dir/2007/36/oj & SRD1 & & $\begin{array}{c}2(d) \\
10\end{array}$ \\
\hline https://eur-lex.europa.eu/eli/dir/2009/65/oj & UCITS & & $\begin{array}{c}22(5) \\
23(2)(c)(a)\end{array}$ \\
\hline https://eur-lex.europa.eu/eli/dir/2011/61/oj & AIFM & & 21 \\
\hline https://eur-lex.europa.eu/eli/reg/2012/236/oj & SSR & & $\begin{array}{c}2(\mathrm{I}) \\
11 \\
16\end{array}$ \\
\hline https://eur-lex.europa.eu/eli/reg/2012/648/oj & EMIR & & 39 \\
\hline http://eur-lex.europa.eu/eli/reg_impl/2012/827/oj & & $\underline{\text { AlFM }}$ & $\begin{array}{l}3 \\
4\end{array}$ \\
\hline https://eur-lex.europa.eu/eli/reg/2012/1011/oj & holding stats & & Annexes \\
\hline https://eur-lex.europa.eu/eli/reg_impl/2012/1247/oj & $\begin{array}{l}\text { Trade } \\
\text { Repositories }\end{array}$ & $\underline{E M I R}$ & 3 ter \\
\hline http://eur-lex.europa.eu/eli/reg del/2013/231/oj & & $\underline{\text { OPCVM }}$ & $\begin{array}{l}\text { Section } 3 \\
\text { Section } 4\end{array}$ \\
\hline https://eur-lex.europa.eu/eli/reg/2013/575/oi & CRR & & $\begin{array}{c}207 \\
\text { Title III }\end{array}$ \\
\hline https://eur-lex.europa.eu/eli/dir/2014/65/oj & MIF2 & & $\begin{array}{c}4(1)(15) \\
4(1)(20) \\
4(1)(21) \\
4(1)(24) \\
4(1)(44) \\
4(1)(53) \\
25\end{array}$ \\
\hline https://eur-lex.europa.eu/eli/reg/2014/596/oj & MAR & & Chapter II \\
\hline https://eur-lex.europa.eu/eli/reg/2014/600/oj & MIFIR & $\underline{\text { MIF2 }}$ & $\begin{array}{c}\text { Title II } \\
\text { Title III } \\
\text { Title IV }\end{array}$ \\
\hline https://eur-lex.europa.eu/eli/reg/2014/909/oj & CSDR & & $\begin{array}{c}3(2) \\
9 \\
37\end{array}$ \\
\hline https://eur-lex.europa.eu/eli/reg/2015/848/oj & Insolvency & & 2 (9) (ii) \\
\hline http://eur-lex.europa.eu/eli/reg del/2016/2251/oj & & EMIR & 4 \\
\hline https://eur-lex.europa.eu/eli/reg impl/2017/391/oi & $\begin{array}{l}\text { Internalized } \\
\text { settlements }\end{array}$ & $\underline{\text { CSDR }}$ & all \\
\hline https://eur-lex.europa.eu/eli/dir/2018/843/oj & AML5 & $\underline{\mathrm{CRR}}$ & $\begin{array}{c}1(1)(\mathrm{c})(\mathrm{g}) \\
1(1)(\mathrm{c})(\mathrm{h}) \\
1(2)(\mathrm{d})(19)\end{array}$ \\
\hline https://eur-lex.europa.eu/eli/reg_impl/2018/1212/oj & & $\underline{\text { SRD1 }}$ & all \\
\hline https://eur-lex.europa.eu/eli/reg_del/2018/1229/oj & $\begin{array}{l}\text { settlement } \\
\text { discipline }\end{array}$ & $\underline{\text { CSDR }}$ & all \\
\hline https://eur-lex.europa.eu/eli/reg impl/2019/363/oi & & $\underline{\text { SFTR }}$ & $\begin{array}{l}1 \\
5\end{array}$ \\
\hline https://eur-lex.europa.eu/eli/reg del/2019/980/oj & & Prospectus & 2 \\
\hline
\end{tabular}

